\title{
MATERIALS TO THE LICHEN BIOTA OF WESTERN POMERANIA (NORTHERN POLAND). PART 2
}

\author{
WiesŁaw FaŁtynowicz, AgnieszKa Winkowska-Grześkowiak, Martin Kukwa
}

\begin{abstract}
W. Fałtynowicz, Department of Botany, Faculty of Biological Sciences, University of Wrocław, Kanonia 6/8, 50-328 Wrocław, Poland, e-mail: wieslaw.faltynowicz@uwr.edu.pl

M. Kukwa, Department of Plant Taxonomy and Nature Protection, Faculty of Biology, University of Gdańsk, Wita Stwosza 59, 80-308 Gdańsk, Poland, e-mail: martin.kukwa@ugda.edu.pl

A. Winkowska-Grześkowiak, Department of Plant Taxonomy and Nature Protection, Faculty of Biology, University of Gdańsk, Wita Stwosza 59, 80-308 Gdańsk, Poland
\end{abstract}

(Received: August 16, 2018. Accepted: September 11, 2018)

AвSTRACт. The paper contains a list of 195 lichen species collected in the central part of Western Pomerania (northern Poland).

KeY WORDs: lichens, Western Pomerania, northern Poland

\section{INTRODUCTION}

Western Pomerania is an extremely interesting natural area, and the degree of knowledge of particular elements of nature, despite numerous studies, is still insufficient. The richness of the lichen biota of this area is confirmed by numerous publications issued in recent years, which provide a lot of new data and enrich the list of species of Western Pomerania (eg. KowalewsKa et al. 2000, KuKwa 2000a, b, 2001, 2005a, b, 2007, 2010, KowAlEWSKA \& JANDO 2004, KuKWA \& JABŁoŃSKA 2007, KUKWA \& ZDUŃCZYK 2011, KuKWA et al. 2012).

We have been collecting materials of the lichens of Western Pomerania for over 40 years. The synthesis for the period up to 1990 was published as a monograph (FAŁTYNOWICZ 1992), however, information on the localities of individual species and those collected after the monograph was published were not made public, excluding an article (FAŁTYNOWICZ \& MiąDLIKOWSKA 1990).

The aim of the work is to show that in such a seemingly monotonous area, occupied mainly by poor pine forests and agrocenosis, there is a very large wealth of lichens. The information presented in this article is a result of fieldwork conducted in 1987-1992 in the area between Chojnice, Biała, Miastko and Człuchów and also collected for the master's thesis (WinKowsKa-GrześKowiak 2000). This area, lying on the border of the mesoregions: the Bytowskie Lake District, the Charzykowska Plain and the Krajeńskie Lake District, was not penetrated earlier by the lichenologists and turned out to be extremely interesting. A large diversity of habitats and plant communities, diverse geomorphological and climatic conditions as well as the presence of extensive forest complexes being an extension of Bory Tucholskie Forest - are factors that determine richness of lichen biota and presence of numerous taxa very rare in the country.

\section{MATERIALS AND METHODS}

Collected lichens were identified in laboratory using classical methods - stereomicroscope and spot tests. For identification of sterile crustose species, thin layer chromatography (TLC) in solvents A and C was applied (Orange et al. 2001, KubiaK \& KuKwa 2011). Lichens nomenclature is based on Polish checklist of FAŁTYNOWICZ \& KossowsKa (2016), with the exception of Lepra (WEI et al. 2017). Threatened categories of lichens in Poland were assigned according to CIEśLIŃSKI et al. (2006). A list of protected species were prepared on the basis of Regulation of the Minister for Environment in a relation to the protection of fungi species (Regulation... 2014). 
Herbarium materials were deposited in the herbaria of University of Wrocław (WRSL) and University of Gdańsk (UGDA).

Taxa are listed in alphabetical order in the following layout: Latin name of species; numbers of its localities; ecological remarks and others.

List of the localities (in brackets the numbers of squares according to the ATPOL grid - see CIEŚLIŃSKI \& FAŁTYNOWICZ 1993):

1 - Pietrzykowo, $1 \mathrm{~km}$ to the $\mathrm{S}$ (Bc-20); 2 - Pietrzykowo, $2.5 \mathrm{~km}$ to the $\mathrm{E}$ (Bc-21); 3 - Bielsko train station, $2 \mathrm{~km}$ to the $\mathrm{E}$ (Bc-30); 4 - between Wilkowo and Załęże, along a road to Lipczynek (Bc-30); 5 near forest unit Żołna (Bc-31); 6 - Nowa Brda (Bc31); 7 - Lipczynek (Bc-31); 8 - Bagno Biel near Lipczynek (Bc-31); 9 - Bagnisko Niedźwiady near Żołna (Bc-31); 10 - Bagno Czysta (Bc-31); 11 - Stary Most forest unit, $0.5 \mathrm{~km}$ to the $\mathrm{S}$ along small river Chocina (Bc-31); 12 - Stary Most forest unit, $0.5 \mathrm{~km}$ to the W (Bc-31); 13 - Nowa Brda, $4 \mathrm{~km}$ to the NW (Bc31); 14 - NE edge of Lipczyno Lake (Bc-31); 15 Turzyniec (Bc-31); 16 - between Bagno Biel and Lipczynek (Bc-31); 17 - Nowa Karczma by Kiełpińskie Lake (Bc-32); 18 - Popielewo near Zielona Chocina (Bc-32); 19 - between Sporysz and Międzybórz (Bb49); 20 - Wiśnica forest unit, $0.5 \mathrm{~km}$ to the $S$ (Bc40); 21 - Sporysz, $3.5 \mathrm{~km}$ to the E (Bc-40); 22 - Suszka (Bc-40); 23 - Suszka, $2.5 \mathrm{~km}$ to the NW (Bc-40); 24 - Ruda, $1.5 \mathrm{~km}$ to the S (Bc-40); 25 - by Żukowo Lake, to the W from Suszka (Bc-40); 26 - Przyton, $2 \mathrm{~km}$ towards Miastko (Bc-40); 27 - Przyton, at the bridge on the Brda (Bc-41); 28 - Przytoń, $1.5 \mathrm{~km}$ to the NE (Bc-41); 29 - Świerkówko (Bc-40); 30 - Nowa Wieś (Bc-41); 31 - between Nowa Wieś and Nowa Brda, along the railway embankment (Bc-41); 32 Przechlewo, $2 \mathrm{~km}$ to the W (Bc-41); 33 - between Przechlewo and Przechlewko (Bc-41); 34 - Przechlewo (Bc-41); 35 - shore of the Brda river, to the $S$ from Nowa Brda (Bc-41); 36 - Krasne Lake, $1 \mathrm{~km}$ to the W (Bc-41); 37 - Krasne Lake, $1.5 \mathrm{~km}$ to the E (Bc41); 38 - Międzybórz (Bb-59); 39 - Dzików-Breńsk (Bc-50); 40 - Rzeczenica, $2 \mathrm{~km}$ to the W (Bc-50); 41 - Kopernica, $3 \mathrm{~km}$ to the SW (Bc-52); 42 - Rzeczenica (Bc-50); 43 - Pakotulsko (Bc-40); 44 - Gwieździn (Bc-50); 45 - Zawada (Bc-50); 46 - Jemielno (Bc42); 47 - Polnica (Bc-52); 48 - Szczytno (Bc-50); 49 - Płaszczyca (Bc-51); 50 - Pawłówko (Bc-51); 51 - between Pakotulsko and Przechlewo (Bc-40); 52 between Przechlewo and Sąpólno (Bc-41); 53 - Lisewo (Bc-51); 54 - between Sąpólno and Jemielno (Bc41); 55 - Dobrzyń (Bc-50); 56 - between Pakotulsko and Rzeczenica (Bc-40); 57 - between Stołczno and Gwieździn (Bc-40); 58 - between Zawada and Rzeczenica (Bc-40); 59 - between Pawłówko and Polnica (Bc-51); 60 - Przechlewo, forest to the SE (Bc-41); 61 - between Lisewo and Pawłówko (Bc-51); 62 - between Szczytno and Dobrzyń (Bc-50); 63 - Stołczno (Bc-61); 64 - Pawłówko, forest to the SE (Bc-61); 65
- by Końskie Lake (Bc-50); 66 - Jemielno, forest to the E (Bc-42); 67 - Szczytno Lake, forest to the S (Bc50); 68 - between Płaszczyca and Lisewo (Bc-51); 69 - between Lisewo and Dobrzyń (Bc-51).

\section{LIST OF SPECIES}

Acarospora fuscata (Nyl.) Arnold - on stones, boulders, and granite posts: $1-4,7,8,14,15,22,23$, 30, 31, 33, 34, 37, 39, 43, 59, 60.

Acarospora moenium (Vain.) Räsänen - on concrete: 4, 7, 10, 11, 14, 15, 24, 27, 34, 45-48, 55, 57, 63.

Acarospora veronensis A. Massal. - on a boulder: 3 .

Acrocordia gemmata (Ach.) A. Massal. - on Sorbus aucuparia bark: 7.

Alyxoria varia (Pers.) Ertz \& Tehler - on Acer platanoides bark: 6 .

Amandinea punctata (Hoffm.) Coppins \& Scheidegger - on bark of deciduous trees, exceptionally on Picea abies: 1-3, 6, 11, 13, 17, 19, 20, 30, 32, 34, 37-40, 43-45, 49-51, 53, 54, 56-60.

Anaptychia ciliaris (L.) Körb. - on bark of deciduous roadside trees: $6,7,34,41,49,52,53,62$.

Arthonia spadicea Leight. - on smooth bark of Corylus avellana, Fagus sylvatica, and Alnus glutinosa, at the base of the trunks: 5, 26 .

Athalia holocarpa (Hoffm.) Arup, Frödén \& Søchting - on concrete: 7, 10, 14, 16.

Bacidina sulphurella (Samp.) M. Hauck \& V. Wirth on Fagus sylvatica bark: 45, 53, 56.

Baeomyces rufus (Huds.) Rebent. - on soil and boulders: 7, 14, 23, 31, 36, 64 .

Biatora globulosa (Flörke) Fr. - on bark of Quercus, rarely on Acer platanoides: 3, 6, 11, 15, 29, 52, 59.

Bilimbia sabuletorum (Schreb.) Arnold - on mosses growing on wet concrete: 5,8 .

Bryoria fuscescens (Gyeln.) Brodo \& D. Hawksw. - on bark of deciduous trees, especially Betula pendula, exceptionally on Picea abies and Pinus sylvestris: 3, $4,6-9,15,16,28-30,32,37,51,53,55,56,58$, 59,64 .

Bryoria implexa (Hoffm.) Brodo \& D. Hawksw. - on bark of Betula and Sorbus aucuparia: 8, 16.

Buellia aethalea (Ach.) Th. Fr. - on boulders: 1, 23, 37; rare subatlantic lichen, known from several localities in Poland, located mainly in Western Pomerania and in the Western Beskids (FatTynoWICZ 1993, 2003).

Buellia griseovirens (Turner \& Borrer ex Sm.) Almb. on bark of deciduous trees, exceptionally on Picea and Pinus: 5, 8, 11, 16, 26, 27, 45, 51, 52, 58, 59, 62,65 .

Caeruleum heppii K. Knudsen \& L. Arcadia - on small pebbles along the sandy roadside: 8 .

Calicium adspersum Pers. - on bark of an old Quercus: 13.

Calicium glaucellum Ach. - on wood: 9; rare in the country, probably overlooked. 
Calicium salicinum Pers. - on bark of Alnus glutinosa and Acer platanoides: 5, 6.

Calicium viride Pers. - on bark of Quercus and Betula: 8, 13.

Calogaya decipiens (Hoffm.) Arup, Frödén \& Søchting - on concrete: $5,7,11,16,19,22,27,36,37$, $39,42,45,47-50$.

Calogaya pusilla (A. Massal.) Arup, Frödén \& Søchting - on concrete: $7,16,37$.

Caloplaca teicholyta (Ach.) Steiner - on concrete: 37.

Candelaria concolor (Dicks.) B. Stein s.l. - on bark of Betula, Acer platanoides, and Robinia pseudacacia: 6, 34, 45, 50-52, 62.

Candelariella aurella (Hoffm.) A. Zahlbr. - on concrete, exceptionally on small limestone pebbles: $3,5,7,8,10,11,14-16,19,22,24,27,30,31,34$, 36, 38, 40, 44, 46, 47, 50, 54, 55.

Candelariella coralliza (Nyl.) H. Magn. - on boulders: 1-3, 7, 22.

Candelariella vitellina (Hoffm.) Müll. Arg. - on boulders, exceptionally on Quercus bark: 15-17, 33, $37-39,52$.

Candelariella xanthostigma (Ach.) Lettau - on bark of deciduous trees, mainly on Acer platanoides: 6, 7, 24, 30, 32, 34, 37-40, 45, 48-52, 54, 56, 57, $62,63$.

Carbonicola anthracophila (Nyl.) Bendiksby \& Timdal - on decaying pine wood and on peatlands' Betula bark: 8, 9; the species is more numerous and more often found only in north-eastern Poland; in the remaining area very rare in dispersed localities (CIeśLIŃSKI 1993, JANDO \& KuKWA 1999, KubiaK et al. 2010, SchiEfelBein et al. 2012).

Cetraria aculeata (Schreb.) Fr. - on soil, exceptionally on bark of Betula and on wood: 3, 7, 8, 14, 15, $18,23,29,33,36,38,46,47,52,58,61,64,66$.

Cetraria ericetorum Opiz - on the ground in the forest margins, in exposed places: $29,33,58,61,64$, 66.

Cetraria islandica (L.) Ach. - on the ground in the dry pine forests and their margins, in many localities very numerous, and even occurs en masse (eg. in locality 18): 10, 14-16, 18, 22, 29, 30, 36, $46,47,50,53,58,61,64,66$.

Cetraria sepincola (Ehrh.) Ach. - on Betula twigs, exceptionally on bark of Pinus sylvestris and Alnus glutinosa: 2, 5, 7-11, 14, 15, 19, 27, 33, 38, 41.

Chaenotheca chrysocephala (Ach.) Th. Fr. - on bark of Betula, Quercus, and Alnus glutinosa: 5, 8, 9, 12, 14, 29, 35.

Chaenotheca ferruginea (Turner ex Sm.) Migula - on bark of Pinus sylvestris and Alnus glutinosa, exceptionally on Picea, Quercus, Betula, and wood: 5, 7-9, $14,43,50,53,61,64,66$.

Chaenotheca furfuracea (L.) Tibell - on Fagus sylvatica bark and on soil in forests: 26, 27, 35.

Chaenotheca trichialis (Ach.) Th. Fr. - on Alnus glutinosa bark in riverside forest: 5 .
Chrysothrix candelaris (L.) J.R. Laundon - on bark of deciduous trees, mainly of Quercus: 5, 6, 13, 20, $21,26,61,64$.

Circinaria calcarea (L.) A. Nordin, Savič \& Tibell - on concrete: 14, 24, 27, 36.

Cladonia arbuscula (Wallr.) Flot. \& Ruoss - on soil: $2-4,7-10,14-16,18,22,23,27-29,31,33,36$, $38,41,44-46,50-52,60,61,64,66$.

Cladonia botrytes (Hagen) Willd. - on the upper surface of pine stumps: $2,9,10,13,16,43,46,50$, $53,56,64$.

Cladonia cariosa (Ach.) Spreng. - on the ground in dry swards covering railway embankment: 31 , 50,63 , rarely recorded in the western part of the country, mainly in anthropogenic habitats (railway embankments, roadside, gravel pits), much more common in the NE of Poland in dry grasslands (CIEśLIŃSKI 2003).

Cladonia cenotea (Ach.) Schaer. - on wood, soil and at the base of tree trunks: 2, 5, 8-12, 14, 25, 29, 50, 53, 56, 59, 64, 67.

Cladonia cervicornis (Ach.) Flot. subsp. verticillata (Hoffm.) Ahti - on soil in dry swards and heathlands: 3, 7-9, 16, 23, 28, 33, 36, 38, 56, 61, 64, 68.

Cladonia chlorophaea (Flörke ex Sommerf.) Spreng. s.l. - on soil, wood, rarely on bark at the base of tree trunks: 2-11, 14, 16, 19, 20, 22, 23, 27-29, $31,34,36,38,41,42,43,45-62,64,68$.

Cladonia ciliata (Stirt.) Harm. var. tenuis (Flörke) Nimis - on soil: 9, 28, 45, 46, 50, 58, 61, 64, 66.

Cladonia coccifera (L.) Willd. - on soil in dry swards: 3, 59.

Cladonia coniocraea (Flörke) Spreng. (syn. C. ochrochlora Flörke) - on bark at the base of tree trunks, rarely on wood and soil: 2, 3, 5-12, 14, $15,19-22,24-29,26,38,41,46,55-57,59,60$, 64, 67, 69.

Cladonia cornuta (L.) Hoffm. - on soil, wood, and bark of inclined Betula: 3, 7-9, 16, 20, 24, 28, 29, 36, 38, 41, 46.

Cladonia crispata (Ach.) Flot. - on soil and wood: 7, 9.

Cladonia deformis (L.) Hoffm. - on soil, rarely on wood: 3, 7-10, 14, 16, 23, 27-29, 38, 46, 50, 52, $56,59,64,66,67$.

Cladonia digitata (L.) Hoffm. - on wood and bark at the base of tree trunks, rarely on soil: $3,5,7-10$, $12,14,20,22,26,27,29,41,46,56,59,61,64$, $66,67$.

Cladonia fimbriata (L.) Fr. - on wood, soil, and on bark at the base of tree trunks, exceptionally on mosses: 3, 5-11, 14, 19-22, 24, 25, 27, 28, 31, $33,36,38,41,43,46,48-50,52,55,56,59-61$, $64,66,67$.

Cladonia floerkeana (Fr.) Flörke - on wood and soil, exceptionally on Betula bark: 2, 3, 7-9, 18, 25, 29, $36,38,43,44,46,49,52,56,59,61,64,66,67$. 
Cladonia furcata (Huds.) Schrad. - on soil, rarely on wood: 3, 4, 7-11, 14, 16, 18-20, 27-29, 34, 36, $38,41,44-47,49,50,52,53,56-61,64,66,67$.

Cladonia glauca Flk. - on wood and bark at the base of tree trunks, rarely on soil: $2,3,5,7-10,12$, $14,16,18-20,23-29,31,36,38,41,44-47,49$, $51-53,56-61,63,64,66,67$.

Cladonia gracilis (L.) Willd. - on soil, rarely on wood: $3,7,9-11,14,16,18,20,22,23,27-29,36,41$, $46,50-52,55,59,61,66,67$.

Cladonia macilenta Hoffm. - on wood, soil, and tree trunks: $2,3,8-10,12,16,18,20,22,26-29,36$, $38,41,43,44,46,49,52,53,56,58,59,61,64$ 67.

Cladonia phyllophora Hoffm. - on soil, exceptionally on wood: $3,7,9,14,16,22,27,28,31,36,38,41$, 46, 49, 51, 52, 61, 62, 64, 66, 67.

Cladonia pleurota (Flörke) Schaerer - on soil in dry swards, rarely on Betula bark: 2, 3, 7, 14, 22, 23, 36, 38, 56, 59, 66.

Cladonia polydactyla (Flörke) Sprengel - on soil in the beech forest on the slope above the Wda river: 26; the lichen characteristic for the base of trunks in deciduous forests, rarely recorded in the country, probably overlooked.

Cladonia portentosa (Dufour) Coem. - on soil in the dry and marsh pine forests: $8-10,14,16,27,28$, $66,67$.

Cladonia pyxidata (L.) Hoffm. s.l. - on soil, exceptionally on Betula bark: 3, 8, 9, 31, 46, 52, 56, 57, 59-61, 64, 66.

Cladonia rangiferina (L.) Weber - on soil, rarely on wood: $3,4,7-10,14-16,18,22,27-29,41,46$, $50,51,55,61,64,66,67$.

Cladonia rangiformis Hoffm. - on soil in sunny places: 14,66 .

Cladonia rei Schaer. - on soil: 56, 60, 65.

Cladonia scabriuscula (Delise) Nyl. - on soil: 19, 27, $31,53,60,64,66$.

Cladonia stellaris (Opiz) Pouzar \& Vězda - on soil in dry pine forests, numerous but in the form of small specimens: 37,66 .

Cladonia subulata (L.) Weber in Wigg. - on soil, exceptionally on wood: $2,3,7,8,11,14,16,19,22$, $28,29,31,33,38,46,47,49,50,52,56,57,59$, $61,64-68$.

Cladonia uncialis (L.) Wigg. - on soil, exceptionally on wood: $3,7-10,14-16,18,22,23,28,29,36$, $46,48,52,55,61,64,66,67$.

Cliostomum griffithii (Sm.) Coppins - on bark of a Sorbus aucuparia: 7.

Coenogonium pineti (Schrad.) Lűcking \& Lumbsch on bark of Quercus, Acer platanoides, Picea abies, and Corylus avellana: 27, 43, 45, 59, 65.

Cyphelium inquinans (Sm.) Trevis. - on bark of an old, decaying Betula on a bog, a few thalli with several fruit bodies: 8; very rare species in Poland, known only from six dispersed localities (see FAETYNOWICZ 2002).

Dibaeis baeomyces (L.) Rambold \& Hertel - on soil in the heathland: 23 .

Evernia prunastri (L.) Ach. - on bark of deciduous trees: 1, 5-8, 11-13, 17, 19-21, 24, 26, 27, 29, 30, 32-34, 37, 39-46, 49-53, 56, 59, 65.

Flavoplaca citrina (Hoffm.) Arup, Frödén \& Søchting - on concrete: $5,10,14,16,22,24,30,34,36,37$, 39, 43-45, 47, 49.

Graphis scripta (L.) Ach. - on bark of Fagus sylvatica and Corylus avellana: 11, 26, 27, 35.

Hypocenomyce scalaris (Ach.) M. Choisy - on bark of deciduous and coniferous trees and wood, exceptionally on soil and boulders; in the localities 2, 9, 15 , and 24 - with apothecia; very common in the whole investigated area: 1-32, 34, 35, 38-69.

Hypogymnia farinacea Zopf - on bark of deciduous and coniferous trees and on wood, very often: $6-9,11,13,15,20,21,24-26,28,29,38,39,41$, $43,56$.

Hypogymnia physodes (L.) Nyl. - on bark of deciduous and coniferous trees and on wood, exceptionally on boulders, common and en masse: 1-9, 11-15, 17-30, 32-69.

Hypogymnia tubulosa (Schaer.) Havaas - on bark of deciduous trees: $1,8,15,16,19,21,24,27,30$, $32,34,38,40,43,45,46,49-52,55,56,59-62$, 65,67 .

Imshaugia aleurites (Ach.) Fricke Meyer - on bark of Pinus sylvestris, exceptionally on Betula, Populus tremula, and on wood: $3,7-10,12,14,23,26$, 28-30, 41, 47, 50.

Lecanora argentata (Ach.) Malme (syn. L. subrugosa Nyl.) - on bark of deciduous trees: 4, 7, 13, $16,24,26,35,37,41,42,45,48,51,53,55-57$, 60-62, 65.

Lecanora carpinea (L.) Vain. - on bark of deciduous trees: 7, 24, 35, 42, 43, 49-52, 55, 62, 65.

Lecanora chlarotera Nyl. - on bark of Acer platanoides, Populus, Salix, and Sorbus aucuparia, rarely on wood: 3, 7, 8, 24, 32, 34, 37, 40, 41, 43, 48-51, 53.

Lecanora conizaeoides Nyl. ex Crombie - on bark of trees and shrubs and on wood, common and en masse: 2-13, 15-24, 26-29, 33, 34, 36-69.

Lecanora expallens Ach. - on bark of deciduous trees, rarely on wood: $2-6,8,11,13,15,19-21,24,26$, $27,29,30,32,34,35,39-41,43,45,46,48-52$, $55-59,61,66,67$.

Lecanora intricata (Ach.) Ach. - on boulder: 37; very rare in the northern part of the country (FAETYNOWICZ 1992, CIEŚLIŃSKI 2003), much more frequent in the mountains and on the foothills (see eg. KośCIELNIAK 2013).

Lecanora polytropa (Ehrh.) Rabenh. - on boulders and stones: $1-4,7,8,14,15,20,22-24,28,30$, 31, 33, 37-39, 42, 43, 45, 52, 55. 
Lecanora pulicaris (Pers.) Ach. - on bark of deciduous trees, exceptionally on Pinus sylvestris: 3, 8, 9, $16,27,34,35,40,41,43-45,48,50,53,54,59$, 65.

Lecanora saligna (Schrad.) A. Zahlbr. - on bark of deciduous trees: $13,34,37,40,44,45,49,50,53$, $55,56,58$.

Lecanora sarcopidoides (A. Massal.) A.L. Sm. - on decaying pine wood: 24 ; the species rarely recorded in Poland (see CieśLIŃski 2003, FAŁTYNowicz 2003).

Lecanora symmicta (Ach.) Ach. - on bark of Pinus sylvestris, Populus tremula, Betula, Picea, and on wood: 8, 9, 29, 41, 45, 65.

Lecanora umbrina (Ehrh.) A. Massal. - on bark of Betula and Acer platanoides: 9, 50, 52, 56.

Lecanora varia (Ehrh.) Ach. - on bark of deciduous trees and on wood: $14,29,30,43,48,51,52,54$, $55,57,61,65$.

Lecidea fuscoatra (L.) Ach. - on boulders: 2, 4, 7, 8, 15, 22, 23, 28, 33, 39.

Lecidella elaeochroma (Ach.) M. Choisy - on bark of Populus tremula and Sorbus aucuparia, rarely on wood: $7,8,41,52,53,55$.

Lecidella stigmatea (Ach.) Hertel \& Leuckert - on concrete: $14-16,19,22,30,36-40$.

Lepra albescens (Huds.) Hafellner - on bark of deciduous trees, exceptionally on Pinus: 2, 5, 6, 8, 9, 12, $14,16,18,24-26,28-30,32,38,40,44,51-54$, $56,65-67$.

Lepra amara (Ach.) Hafellner - on bark of deciduous trees and Corylus avellana: $1-3,5-8,11-13,15$, 19-21, 24-27, 29, 32, 34, 35, 38, 39, 42, 44, 45, $48,49,51,52,54-56,59$.

Lepraria elobata Tønsberg - on bark of an Quercus, Betula and on wood: 59, 61, 65, 66.

Lepraria incana (L.) Ach. - on bark of deciduous and coniferous trees and on wood: $43-46,48-52,54$ 69.

Lepraria jackii Tønsberg - on bark of deciduous and coniferous trees and on wood: 49-62, 64-69.

Lepraria rigidula (B. de Lesd.) Tønsberg - on bark of deciduous and coniferous trees: 44, 48, 50, 58, 59,64 .

Lepraria vouauxii (Hue) R.C. Harris - on mosses and concrete, numerous: 5 .

Melanelixia glabratula (Lamy) O. Blanco et al. - on bark of deciduous trees and shrubs: $3,4,6,7,11$, 13, 20, 24-27, 29, 30, 52, 56.

Melanohalea elegantula (Zahlbr.) O. Blanco et al. - on bark of Acer platanoides: 56.

Melanohalea exasperatula (Nyl.) O. Blanco et al. on bark of deciduous trees: $1,6,30,32,34,37$, $41-53,56,57,60,63,65,68$.

Micarea denigrata (Fr.) Hedl. - on Betula bark and on wood: $6,14,52,56,61$.

Micarea melaena (Nyl.) Hedl. - on Pinus sylvestris bark at the base of trunks and on wood, numerous: 9; in Western Pomerania very rare, frequent in north-eastern Poland and in the highlands and mountains (CZARNOTA 2007).

Micarea misella (Nyl.) Hedl. - on Pinus sylvestris bark: 50, 57, 64 .

Micarea prasina Fr. - on bark of deciduous trees and Pinus sylvestris and on wood: 3, 46, 50, 52, 56, 59, 68, 69.

Montanelia sorediata (Ach.) Divakar et al. - on boulders, sparsely: 1, 7; very rare taxon, known from dispersed localities mainly in northern Poland (see FaetyNowicz 1992, SzCZEPAŃSKa et al. 2015).

Mycoblastus sanguinarius (L.) Norm. - on bark of an old, decaying Betula on a raised bog, a dozen patches with fruiting bodies: 8 , very rare species in the lowlands, more frequent in the mountains, but everywhere disappearing (FAtTYNOWICZ 2003).

Myriolecis albescens (Hoffm.) Śliwa et al. - on concrete: $3,5,7,8,10,11,16,19,22,24,30,34,36$ 39, 45-47, 49, 50, 52, 53, 55.

Myriolecis dispersa (Pers.) Śliwa et al. - on concrete, rarely on limestone pebbles: $3,5,7,8,10,11,14$ $16,19,22,24,26,27,31,34,36-40,42,44-49$, $54,55$.

Myriolecis hagenii (Ach.) Śliwa et al. - on bark of Populus, Salix, Quercus, Acer, on wood and concrete: $3,8,27,30,36,45,50-52,57,60,62$.

Ochrolechia microstictoides Räsänen - on Betula bark: $6,51,60,64$.

Parmelia saxatilis (L.) Ach. s.l. - on bark of Fagus, Betula, and Quercus and on boulders: 2, 8, 11, 12, 16, 20, 25, 27, 43, 69.

Parmelia sulcata Taylor - on bark of deciduous trees, exceptionally on boulder: $1,4-8,11-14,16,17$, 19-21, 24-27, 29, 30, 32-35, 37(c.ap.), 38-53, $56,57,60,61,63-65$.

Parmeliopsis ambigua (Wulfen in Jacq.) Nyl. - on bark of deciduous trees and Pinus sylvestris and on wood: 2-5, 7-12, 14-16, 18, 20, 22, 24-30, 34, $35,38,41,46,50,52,54-56,60,61,64,65,67$.

Peltigera canina (L.) Willd. - on soil: 8, 15, 59, 65.

Peltigera didactyla (With.) Laundon - on soil: 16, 28, 31, 44, 51, 55, 60, 64.

Peltigera neckeri Hepp ex Múll. Arg. - on soil: 36; rarely noted, known for dispersed localities in the country (MiądLIKOWSKA \& FAŁTYNOWICZ 2003).

Peltigera polydactylon (Neck.) Hoffm. - on soil: 7, 16, 36.

Peltigera ponojensis Gyeln. - on soil: 60, 66.

Peltigera praetextata (Flörke) Zopf - on soil and mosses: 5, 26, 56.

Peltigera rufescens (Weiss) Humb. - on soil in dry swards: $7,8,15,19,27,28,31,34,49,51,52,56$, 57, 59, 60, 64, 66, 68.

Pertusaria coccodes (Ach.) Nyl. - on bark of Acer platanoides, Fagus, Quercus, and Carpinus: 20, 24, 26, 27, 46, 55, 57, 62, 65.

Pertusaria flavida (DC.) J.R. Laundon - on bark of old Quercus: 13, 21. 
Pertusaria pertusa (L.) Tuck. - on Fagus bark, exceptionally on Betula: 8, 26, 27, 35.

Phaeophyscia nigricans (Flörke) Moberg - on concrete: $7,10,19,30,34,36,37,46,47,50,54,55$, 65.

Phaeophyscia orbicularis (Neck.) Moberg - on concrete and on bark of deciduous trees, especially Populus and Acer: 5-8, 11, 14, 17, 19, 24, 30-32, 34, 36, 37, 39, 42, 44, 47-52, 54-56, 60.

Phlyctis argena (Ach.) Flot. - on bark of deciduous trees: $1-8,11,12,15,17,19,20,24,27,29,30$, 32, 34, 37, 39-41, 43-45, 47-59, 59-62, 65.

Physcia adscendens (Fr.) H. Olivier - on concrete and on bark of deciduous trees, especially Populus and Acer: 6, 15-17, 19, 27, 29, 30, 32, 34, 36, 37, 39$42,44-48,51-57,60-63,65$.

Physcia caesia (Hoffm.) Fürnrohr - on concrete, rarely on boulders: $5,7,8,19,26,27,31,33,36,37$, 39, 40, 45, 54, 55.

Physcia stellaris (L.) Nyl. - on bark of Populus: 6, 30, $34,49,53,62$.

Physcia tenella (Scop.) DC. - on bark of deciduous trees, rarely on wood, boulders, and concrete: $5-7,11,19,22,24,29,30,32-34,36-38,41,43-$ $56,58-63,65,68$.

Physconia distorta (With.) J.R. Laundon - on bark of deciduous trees, especially Populus tremula: 6, 7, 24, 30, 32, 34, 37, 39, 40, 48, 50-52, 54.

Physconia enteroxantha (Nyl.) Poelt - on bark of Acer platanoides, Salix, and Fraxinus: 6, 19, 24, 27, 29, 30, 34, 37, 39, 40, 51, 52, 54, 56, 58, 64.

Physconia grisea (Lam.) Poelt - on bark of Salix and Acer platanoides: 34, 45, 55, 61, 62.

Physconia perisidiosa (Erichsen) Moberg - on bark of Acer platanoides, Salix, and Populus: 6, 30, 34, 45, $48,50,56$.

Placynthiella dasaea (Stirt.) Tønsberg - on bark of deciduous and coniferous trees and on wood, and soil: 43, 45, 58, 61 .

Placynthiella icmalea (Ach.) Coppins \& P. James - on bark of deciduous trees, on wood and soil: 43 , 45-47, 49, 51, 52, 54, 56-62, 64-69.

Placynthiella oligotropha (Vain.) Coppins \& P. James - on soil, rarely on wood and Quercus bark: 3, 7-10, 13, 14, 26, 58, 60.

Placynthiella uliginosa (Schrad.) Coppins \& P. James - on wood and soil: $3,5,8-10,14,20,22,23$, 27-29, 38, 57, 60, 61, 64.

Platismatia glauca (L.) W. Culb. \& C. Culb. - on bark of deciduous and coniferous trees, exceptionally on boulder: $2-16,18,20-22,24-30,34,35,38$, $40,41,43,46-48,51,54,56,58-61,64,69$.

Pleurosticta acetabulum (Neck.) Elix \& Lumbsch on bark of deciduous trees, mainly Populus tremula and Acer platanoides: 6, 7, 17, 24, 30, 32, 34, 37, 40, 42, 43, 45-50, 52-56, 65.

Polycauliona candelaria (L.) Frödén, Arup \& Søchting - on bark of deciduous trees, mainly Populus tremula: 1, 5, 17, 19, 30, 32, 34, 37, 42-58, 60-63, $66,68$.

Polycauliona polycarpa (Hoffm.) Frödén, Arup \& Søchting - on bark of deciduous trees, exceptionally on Picea and on boulder: 30, 34, 38, 42-57, $60,62,63,65,68$.

Porina aenea (Wallr.) A. Zahlbr. - on bark of Fagus, Corylus, Padus avium, and on wood: 6, 27, 46, 60.

Porpidia crustulata (Ach.) Hertel \& Knoph - on a boulder: 3 .

Porpidia tuberculosa (Sm.) Hertel \& Knoph - on boulders: 7, 8, 28.

Protoparmeliopsis muralis (Schreb.) M. Choisy - on concrete, boulders and stones: 7, 17, 26, 37-39, 34, 42, 44, 45, 47, 48, 50, 52, 53, 55, 63, 64 .

Pseudevernia furfuracea (L.) Zopf - on bark of deciduous and coniferous trees and on wood, exceptionally on boulder: $1-4,6-10,14-24,26-32,34$, 37-46, 48, 49, 51-67, 69.

Ramalina farinacea (L.) Ach. - on bark of deciduous trees, mainly Acer and Quercus: 2, 5, 6, 8, 11-13, $19,21,24,26,27,29,30,33,34,37,40-46,48-$ 50, 52, 54-57, 59-63, 68.

Ramalina fastigiata (Pers.) Ach. - on bark of Populus tremula, Acer platanoides, and Salix: 6, 7, 16, 30, 41, 52.

Ramalina fraxinea (L.) Ach. - on bark of deciduous trees, mainly Acer and Populus: 6-8, 13, 24, 30, 32-34, 37, 39-41, 45, 46, 48-52, 54, 57, 63, 68.

Ramalina pollinaria (Westr.) Ach. - on bark of Acer and Quercus: 34, 37, 50, 52, 62.

Rinodina oleae Bagl. - on concrete: 43, 45, 47.

Rusavskia elegans (Link.) S.Y. Kondr. \& Kärfnefelt on concrete: 7, 34, 36, 37, 45, 47, 54, 63.

Sarcogyne regularis Körb. - on concrete and small limestone pebbles: 14, 31 .

Scoliciosporum chlorococcum (Graeve ex Stemham.) Vězda - on bark of coniferous and deciduous trees and on wood: $3,7-10,22,27,34,36,37,43,45$, $48,51,52,54,58-60,65$.

Stereocaulon condensatum Hoffm. - on soil of heathlands: 3 (c.ap.), 23.

Stereocaulon tomentosum Fr. - on boulder: 31, very rare, known from few localities, mainly in northern Poland (Oset 2014).

Strangospora moriformis (Ach.) Stein - on Betula bark: 52 .

Strangospora pinicola (Massal.) Körb. - on bark of deciduous trees: $30,34,43,45,48,50,52-54,57$, $62,63$.

Thelocarpon intermediellum Nyl. - on wood: 61.

Thelocarpon laureri (Flot.) Nyl. - on stones: 3, 16, 30.

Trapelia coarctata (Sm.) M. Choisy - on a stone: 30 .

Trapelia obtegens (Th. Fr.) Hertel - on boulders: 7, 8

Trapelia placodioides Coppins \& P. James - on stones and boulders: 43, 60, 61 . 
Trapeliopsis flexuosa (Fr.) Coppins \& P. James - on wood, bark of Betula and Pinus sylvestris, exceptionally on Quercus: 3, 7-9, 14, 18, 20, 29, 34, 38, $45,58,64,67$.

Trapeliopsis granulosa (Hoffm.) Lumbsch - on wood, rarely on trees bark at the base of trunks: $2,3,5$, $7-10,12,14,15,19,20,23,24,26-29,31,36,46$, $47,51,52,56,58-62,64,66-69$.

Tuckermannopsis chlorophylla (Willd.) Hale - on bark of deciduous trees, mainly Acer and Betula, exceptionally on Picea: 2-4, 6-8, 15-21, 24, 26-28, 30, $32,34,37-40,44-46,48-50,52,56,58,60,64$, 66.

Umbilicaria polyphylla (L.) Baumg. - on boulder (numerous) and on granite posts (1 specimen with 1 $\mathrm{cm}$ in diameter): 2, 30; very rare in the lowlands, known from few localities.

Usnea dasopoga (Ach.) Röhl. - on bark of deciduous trees: $6,7,9,11,12,16,21$.

Usnea hirta (L.) Weber ex F.H. Wigg. - on bark of deciduous trees and Pinus: 6-9, 15, 16, 20, 29, 30, $34,42,43,47,51-56,58,62,65,69$.

Usnea subfloridana Stirton - on bark of deciduous trees, mainly Betula: 7, 9, 18, 21, 23, 26, 34.

Varicellaria hemisphaerica (Flk.) Schmitt \& Lumbsch - on bark of deciduous trees, mainly Fagus, Quercus, and Alnus: 5, 6, 13, 20, 21, 25-27.

Verrucaria muralis Ach. - on concrete: 7, 15.

Verrucaria nigrescens Pers. - on concrete: 7, 15, 24, 27, 36.

Violella fucata (Stirt.) T. Sprib. - on bark of Acer platanoides: 42, 45.

Vulpicida pinastri (Scop.) J.E. Mattsson \& Lai - on bark of Pinus sylvestris and Betula, on Vaccinium uliginosum twigs, and on decaying wood: 8, 9, 63-65.

Xanthomendoza ulophyllodes (Räsänen) Søchting, Kärnefelt \& S.Y. Kondr. - on bark of an old Populus: 6 , the species with a very poorly understood distribution in Poland, but not very frequent, confused with X. fallax (Hepp) S.Y. Kondr. \& Kärfnefelt.

Xanthoparmelia conspersa (Ach.) Hale - on boulders, exceptionally on concrete: $1,2,4,7,8,39,44,47$, $48,53,56,60$.

Xanthoparmelia loxodes (Nyl.) O. Blanco et al. - on boulders: 1, 7, 8, 24, 38, 39.

Xanthoparmelia mougeotii (Schaer.) Hale - on boulders: 22, 39; the species known in Poland from few localities, mainly in Western Pomerania (see FaŁtyNowicz 2003, Kanigowski et al. 2016).

Xanthoria calcicola Oxner - on concrete: $34,45,47-$ 49, 54, 63.

Xanthoria parietina (L.) Th. Fr. - on bark of deciduous trees and on concrete: $3,6-8,10,16,17,19$, $22,27,29,30,32,34,36-41,44,46-49,50-56$, $58,60,62,63$.

Xylopsora caradocensis (Leighton ex Nyl.) Bendiksby $\&$ Timdal - on dead trunks of Pinus sylvestris on raised bogs, very often and often with apothecia: 8,9 ; in recent years, the species quickly spreading in Poland (see CZarnota 1997, FatTynowicz 2003, KossowsKa \& FAŁTYNowicz 2018).

\section{RESULTS}

It turns out that poor pine forests and peat bogs are very rich in lichen species. We found as many as 195 species of lichens, which is an extremely large number for such a small and seemingly monotonous area. List includes many taxa rare in Poland and even in the lowlands of central Europe, which deserve particular attention: Carbonicola anthracophila, Cyphelium inquinans, Micarea melaena, Mycoblastus sanguinarius, Stereocaulon tomentosum, Thelocarpon intermediellum, Umbilicaria polyphylla, Xanthomendoza ulophyllodes i Xanthoparmelia mougeotii (see also FaŁTYNOWICZ 2003). Very interesting habitat turned out to be the avenues of old deciduous trees along the roads. Low traffic means that the trunks are almost $100 \%$ covered by lichens, among which there are numerous species of rare macrolichens.

In the investigated area, as many as 32 legally protected species and 37 species from the red lichen list of Poland were found (Table 1). Some of them

Table 1. Protected and endangered lichens

\begin{tabular}{|c|c|c|}
\hline Species & Law protection & Threat in Poland \\
\hline Acrocordia gemmata & . & VU \\
\hline Anaptychia ciliaris & + & $\mathrm{EN}$ \\
\hline Bryoria fuscescens & + & VU \\
\hline Bryoria implexa & + & $\mathrm{CR}$ \\
\hline Calicium adspersum & . & $\mathrm{EN}$ \\
\hline Calicium glaucellum & . & VU \\
\hline Calicium salicinum & . & VU \\
\hline Calicium viride & . & $\mathrm{VU}$ \\
\hline Cetraria ericetorum & + & . \\
\hline Cetraria islandica & + & VU \\
\hline Cetraria sepincola & + & $\mathrm{EN}$ \\
\hline Chaenotheca chrysocephala & . & . \\
\hline Chaenotheca trichialis & . & . \\
\hline Chrysothrix candelaris & + & $\mathrm{CR}$ \\
\hline Cladonia arbuscula & + & . \\
\hline Cladonia botrytes & . & $\mathrm{EN}$ \\
\hline Cladonia ciliata & + & . \\
\hline Cladonia portentosa & + & . \\
\hline Cladonia rangiferina & + & . \\
\hline Cladonia stellaris & + & EN \\
\hline Cliostomum griffithii & . & VU \\
\hline Graphis scripta & . & . \\
\hline Hypogymnia farinacea & + & VU \\
\hline Hypogymnia tubulosa & + & . \\
\hline Imshaugia aleurites & + & . \\
\hline Mycoblastus sanguinarius & . & VU \\
\hline Ochrolechia androgyna & . & $\mathrm{VU}$ \\
\hline Peltigera canina & + & VU \\
\hline Peltigera neckeri & + & . \\
\hline
\end{tabular}




\begin{tabular}{lcc}
\hline \multicolumn{1}{c}{ Species } & Law protection & Threat in Poland \\
\hline Peltigera polydactylon & + & $\cdot$ \\
Peltigera praetextata & + & VU \\
Pertusaria flavida & $\cdot$ & EN \\
Pertusaria pertusa & $\cdot$ & VU \\
Physconia distorta & $\cdot$ & EN \\
Physconia perisidiosa & $\cdot$ & EN \\
Pleurosticta acetabulum & + & EN \\
Pyrenula nitida & $\cdot$ & VU \\
Ramalina farinacea & + & VU \\
Ramalina fastigiata & + & EN \\
Ramalina fraxinea & + & EN \\
Ramalina pollinaria & + & VU \\
Stereocaulona condensatum & + & VU \\
Stereocaulon tomentosum & + & EN \\
Tuckermannopsis chlorophylla & + & VU \\
Usnea dasopoga & + & VU \\
Usnea hirta & + & VU \\
Usnea subfloridana & + & EN \\
Varicellaria hemisphaerica & $\cdot$ & VU \\
Vulpicida pinastri & + & $\cdot$ \\
Xanthoparmelia mougeorii & + & VU \\
\hline
\end{tabular}

have very high endangered categories. With category EN were found as many as 12 species, and two are critically endangered (Bryoria implexa and Chrysothrix candelaris); only the first of these species is indeed critically endangered, while the second is relatively frequent, especially in the northern part of the country (see FAŁTYNOWICZ 1992, CieśLIŃSKI 2003).

The results of this study indicate the need to conduct a more accurate inventory of lichens (but also other spore organisms) in anthropogenically transformed areas. They are preserved micro-settlements, which often become refugia of rare species (see also ZARABSKA 2012).

\section{ACKNOWLEDGMENTS}

We would like to thank prof. dr hab. Józef Szmeja (University of Gdańsk) for enabling the first author of multiple stays at organized study camps on Krasne Lake. We also thank Dr Jolanta Miądlikowska (Duke University) for help in the collection of materials and the revision of some species of the Peltigera. Thank you for MSc inż. Hanna Fałtynowicz for linguistic correction.

\section{REFERENCES}

CIEŚLIŃSKI S. (1993): Hypocenomyce anthracophila (Nyl.) P. James \& G. Schneider. In: Atlas of the geographical distribution of lichens in Poland. 1. Instytut Botaniki im. W. Szafera PAN, Kraków: 35-39.
CieśLIŃsKi S. (2003): Atlas rozmieszczenia porostów (Lichenes) w Polsce północno-wschodniej. Phytocoenosis, Supplementum Cartographiae Geobotanicae 15.

Cieśliński S., Czyżewska K., Fabiszewski J. (2006): Red list of the lichens in Poland. In: Z. Mirek, K. Zarzycki, W. Wojewoda, Z. Szeląg (eds). Red list of plants and fungi in Poland. W. Szafer Institute of Botany, Polish Academy of Sciences, Kraków: 71-89.

Cieśliński S., FatTynowicz W. (eds) (1993): Atlas of the geographical distribution of lichenes in Poland. 1. Instytut Botaniki im. W. Szafera PAN, Kraków.

CZARNOTA P. (1997): Hypocenomycetum caradocensis - a new association of epiphytic lichens. Fragmenta Floristica et Geobotanica 42(2): 495-501.

Czarnota P. (2007): The lichen genus Micarea Fr. (Lecanorales, Ascomycota) in Poland. Polish Botanical Studies 23.

Fattynowicz W. (1992): The lichens of Western Pomerania (NW Poland). An ecogeographical study. Polish Botanical Studies 4.

Fattynowicz W. (1993): Buellia aethalea (Ach.) Th. Fr. In: S. Cieśliński, W. Fałtynowicz (eds). Atlas of the geographical distribution of lichens in Poland. 1. W. Szafer Institute of Botany, Polish Academy of Sciences, Kraków: 17-21.

FAetyNowicz W. (2002): Cyphelium inquinans (Sm.) Trevisan. In: U. Bielczyk, S. Cieśliński, W. Fałtynowicz (eds). Atlas of the geographical distribution of lichens in Poland. 3. W. Szafer Institute of Botany, Polish Academy of Sciences, Kraków: 35-38.

FAETYNOWicz W. (2003): The lichens, lichenicolous and allied fungi of Poland - an annotated checklist. W. Szafer Institute of Botany, Polish Academy of Sciences, Kraków.

FatTynowicz W., KossowsKa M. (2016): The lichens of Poland. A fourth checklist. Acta Botanica Silesiaca, Monographiae 8: 3-121.

FAŁTYNowicz W., MiądLIKowsKa J. (1990): Materiały do flory porostów Pomorza Zachodniego (północna Polska). Acta Mycologica 26, 2: 45-64.

Jando K., Kukwa M. (1999) Nowe stanowiska $H y$ pocenomyce anthracophila (Ascomycota lichenisati, Lecideaceae) w Polsce. Fragmenta Floristica et Geobotanica, Ser. Polonica 6: 286-288.

Kanigowski P., Flakus A., Oset M., Kowalewska A., RYKACZEWKi M., KuKWA M. (2016): The lichen family Parmeliaceae in Poland. Xanthoparmelia species containing usnic acid. Herzogia 29(1): 108-119.

Kossowska M., FaŁtynowicz W. (2018): Additions to the lichen biota of the Sudety Mountains. I. Record from the Karkonosze Mountains. Acta Mycologica, in press. 
KowalewsKa A., Jando K. (2004): Chrysothrix flavovirens in Poland. Graphis Scripta 15(1-2): 5152.

Kowalewska A., Kukwa M., Jando K. (2000): Nowe stanowiska rzadkich gatunków porostów w regionie gdańskim. Acta Botanica Cassubica 1: 127-134.

Kubiak D., Kukwa M. (2011): Chromatografia cienkowarstwowa (TLC) w lichenologii. In: M. Dynowska, E. Ejdys (eds). Mikologia laboratoryjna. Przygotowanie materiału badawczego i diagnostyka. Wydawnictwo Uniwersytetu Warmińsko-Mazurskiego w Olsztynie, Olsztyn: 176-190.

Kubiak D., SzymczyK R., Zalewska A., Kukwa M. (2010): Nowe stanowiska rzadkich i interesujących porostów w północnej Polsce. Część 1. Skorupiaste i łuseczkowate porosty sorediowane. Fragmenta Floristica et Geobotanica Polonica 17(1): 131-140.

Kukwa M. (2000a): Pierwsze stanowisko Caloplaca crenulatella (Nyl.) H. Olivier (Teloschistaceae, Ascomycota lichenisati) w północnej Polsce. Acta Botanica Cassubica 1: 139-142.

Kukwa M. (2000b): Stanowisko Trapeliopsis pseudogranulosa (Trapeliaceae, Ascomycota lichenisati) na północy Polski. Fragmenta Floristica et Geobotanica, Ser. Polonica 7: 380-382.

Kukwa M. (2001): Porosty z rodzajów Lepraria Ach. i Leproloma Nyl. ex Cromb. w regionie gdańskim. Acta Botanica Cassubica 2: 123-132.

Kukwa M. (2005a): Nowe stanowiska rzadkich i interesujących porostów na Pomorzu Gdańskim. Część 1. Acta Botanica Cassubica 5: 95-111.

Kukwa M. (2005b): Nowe stanowiska rzadkich i interesujacych porostów na Pomorzu Gdańskim. Część 2. Sorediowane i izydiowane porosty skorupiaste. Acta Botanica Cassubica 5: 113-125.

KukwA M. [2007(2006)]: Nowe stanowiska rzadkich i interesujących porostów na Pomorzu Gdańskim. Część 3. Acta Botanica Cassubica 6: 141-152.

Kukwa M. (2010): Uzupełnienia do listy porostów i grzybów naporostowych Pomorza Gdańskiego. Fragmenta Floristica et Geobotanica Polonica 17(1): 196-199.

KuKwA M., JABŁoŃSKA A. [2007(2006)]: Uzupełnienia do bioty porostowej rezerwatu „Cisy w Czarnem” na Pomorzu Gdańskim. Acta Botanica Cassubica 6: 173-177.

Kukwa M., Kowalewska A., Śliwa L., Czarnota P., Czyżewska K., Flakus A., Kubiak D., Wilk K., Dimos-Zych M., Kolanko K., SzymczyK R., LiPNICKI L., Adamska E., Bielec D., Guzow-Krzemińska B., Gruszka W., HachuŁka M., JabŁońska A., Oset
M., KiszKa J., KoziK J., Leśniański G., Lazarus M. (2012): Porosty i grzyby naporostowe Wdzydzkiego Parku Krajobrazowego (Pomorze Gdańskie, N Polska). Acta Botanica Cassubica 11: 75-103.

KukwA M., ZDuŃCZYK A. (2011): Nowe stanowiska rzadkich i interesujących porostów z Pomorza Gdańskiego i terenów przyległych. Acta Botanica Cassubica 10: 59-73.

Miądlikowska J., FaŁtYnowicz W. (2003): Peltigera Willd. - pawężnica. In: W. Fałtynowicz (ed.). The lichens, lichenicolous and allied fungi of Poland - an annotated checklist. W. Szafer Institute of Botany Polish Academy of Sciences, Kraków: 214-217.

Orange A., James P.W., White F.J. (2001): Microchemical methods for the identification of lichens. British Lichen Society, London.

OsET M. (2014): The lichen genus Stereocaulon (Schreb.) Hoffm. in Poland - a taxonomic and ecological study. Monographiae Botanicae 104.

REgulation of the Minister for Environment in relation to the protection of fungi species - Rozporządzenie Ministra Środowiska w sprawie ochrony gatunkowej grzybów z dnia 16 października 2014 r. (2014). Dziennik Ustaw RP, poz. 1408.

Schiefelbein U., Czarnota P., Thüs H., Kukwa M. (2012): The lichen biota of the Drawieński National Park (NW Poland, Western Pomerania). Folia Cryptogamica Estonica 49: 59-71.

Szczepańska K., Pruchniewicz D., SoŁtysiak J., KossowsKA M. (2015): Lichen-forming fungi of the genus Montanelia in Poland and their potential distribution in Central Europa. Herzogia 28(2): 697-712.

Wei X., Schmitt I., Hodkinson B., Flakus A., Kukwa M., Divakar P.K. et al. (2017): Circumscrtiption of the genus Lepra, a recently ressurected genus to accomodate the "Variolaria" group of Pertusaria sensu lato (Pertusariales, Ascomycota). PLoS ONE 12.7: e0180284, https://doi.org/10.1371/ journal.pone. -180284 .

WiNKOWSKA-GRZEŚKOWIAK A. (2000): Flora porostów północnej części Pojezierza Krajeńskiego. Typescript. MSc thesis. University of Gdańsk.

ZARABSKA D. (2012): Lichens in the agricultural landscape - a floristic and ecological study. Typescript. PhD thesis. Adam Mickiewicz University, Poznań.

For citation: FAŁTYNOWICZ Z., WINKOWSKA-GRZEŚKOWIAK A., KuKwa M. (2018): Materials to the lichen biota of Western Pomerania (northern Poland). Part 2. Steciana 22(2): 41-49. doi:10.12657/steciana.022.006. 